\title{
The Effect of Total Quality Management, Organizational Excellence on Organizational Performance-The Moderating Role of Entrepreneurial Orientation
}

\author{
Abdullah Ibrahim Al-Darmaki(Corresponding author) \\ Sharjah Police Science Academy, Sharjah, United Arab Emirates \\ E-mail: Dr.Abdullahaldarmaki@gmail.com \\ Hassan Saleh Al-Dhaafri \\ University of Dubai, Dubai, United Arab Emirates
}

Received: Jan. 29, 2018 Accepted: March 25, 2018 Published: April 30, 2018

doi:10.5296/jmr.v10i2.12960 URL: https://doi.org/10.5296/jmr.v10i2.12960

\begin{abstract}
Purpose: This study was set up to examine the effect of TQM, organizational excellence on organizational performance.

Design/methodology/approach: To examine the model of the study, design of survey questionnaire was employed through data collected from Al Ain Municipality in the UAE. Out of 200 questionnaires, 135 only usable returned. Partial Least Square (PLS) structural equation modelling was employed to analyze the data.

Findings: Based on statistical results, the effect of TQM, organizational excellence, and organizational performance were confirmed. Moreover, Entrepreneurial orientation was found not supported to moderate the effect of TQM as well as organizational excellence on organizational performance.

Practical implications: The results of this study have several practical implications. This study will help managers and decision makers to take the proper decision when implementing TQM system. Due to that, Entrepreneurial orientation are the most important practices to ease the TQM\& Organizational Excellence implementation.
\end{abstract}




\section{Macrothink

Originality/value: This study is considered as the only empirical study that examines the collective effect of TQM, organizational excellence on organizational performance.

Keywords: Total quality management (TQM), organizational excellence (OE), Entrepreneurial orientation (EO), organizational performance (OP), Al Ain Municipality. 


\section{Introduction}

Today lots of challenges \& obstacles a various organization's \& companies are facing over all the world, however at the same time there are a great ambition to overcome the difficulties \& reach to the planned goals, vision \& goals. This can be achieved through practicing \& executing an innovative strategies \& plans which will foster the journey of fruitful outcomes $\&$ accordingly remaining competitive. To support, advocate the development $\&$ improvement process, organizations have to cope the updated ideas, attitude as well as philosophy of the Total Quality Management \& business excellence (Oakland, 1999).

TQM is a successful tool on the journey of excellence and considered the philosophy of management. It is historical origins back long time. However it is considered as recent term \& a pre -requisite instrument for any organization (McAdam, 2000). It's also as stated by Karuppusami and Gandinatha, 2006, TQM is a continuous improvement of quality as well as satisfying the customer's needs. This study examined the effect of TQM, OE, EO and organizational performance. Due to the inconclusiveness findings in the previous literature of the relationship between TQM, OE and organizational performance, this study is an attempt to investigate the mechanism of TQM and Entrepreneurial orientation as moderator variable that can explain that relationship through implementing quantitative research based on questionnaire survey.

\section{Related Literature and Research Hypotheses}

The literature review is presented in three sections. As a base for understanding the other following relationships, the first section presents the relationship between TQM and organizational performance. Others followed sections will explain the relationships between variables which is HRM, EO and OE and OP. As a result of the thorough discussion of the previous studies in the literature, many hypotheses are proposed for these relationships to be examined in the following parts of this research.

\subsection{TQM and Organizational Performance}

TQM is known as one of the major revolutions of the last years in the area of management. Accordingly its energy or effort to reach \& to beat the various needs of the clients \& forecasting by low expense through continuous improvement of people $\&$ all to be committed to \& concentrating on the methods of organization(Isaksson, 2006).

In the view of (kanji, 2002) TQM Total quality management, it's the management philosophy\& attitude that accelerate an organizational culture committed to clients \& customer satisfaction through continuous improvement.

Some more idea regarding that, Sila(2007) exposed the different variable of the TQM must be in attention for evaluating the linkage between organizational performance \& Total Quality Management, such as leadership, information \& investigation, process management, clients focus, HRM, organizational effectiveness financial and market output, \& supplier management.

Some researchers have conducted some studies in regards to comprehensive literature 
evaluation. Ahire et al. (1995) in regards to TQM strategy testing, he used the MBNQA \& EQA criteria. 226 as empirical woks have been revised, case studies, while the conceptual was accounted approximately from 1970 to 1993 which related to the works on quality management. The outcomes was as the follows, lots of conceptual works have been reported however, there was an important shortage in the empirical \& accordingly they proposed to focus on more empirical investigation \& expanded which related to TQM strategy.

The mixed results in the previous literature of the effect of TQM on organizational performance motivate us to do some further study and to highlight that relationship with the existing of other variables that may help in increasing the positive and significant effect. Therefore, the following hypothesis is proposed:

H1: There is a positive significant relationship between TQM practices and Organizational performance.

H1 a: There is a significant relationship between TQM-Management Leadership and Organizational Performance.

H1 b bThere is a significant relationship between TQM-Strategic Planning and Organizational Performance.

H1 c:There is a significant relationship between TQM-Service Design and Organizational Performance.

H1 d: There is a significant relationship between TQM-Information and Anlaysis and Organizational Performance.

H1 e: There is a significant relationship between TQM-Continuous Improvement and Organizational Performance.

H1 f: There is a significant relationship between TQM-Benchmarking and Organizational Performance.

\subsection{Organizational Excellence and Organizational Performance}

(Peters, W, 1982) has stated that definition of the excellence is commonly connected to the bestseller. It also from their point of view defined excellence in a very vague manner $\&$ it's particularly finance oriented.

Excellence sustains the organization capability to deal with change (Oakland Consultation, 2005). For achieving Business excellence, managers have to have a clear vision \& goal that will lead \& drive the organization to achieve its goals and objectives (Oakland Consultation, 2005), delivering value and managing organizations for stakeholders. Excellence is regarded as the highest level of performance(Antony \& Bahattacharyya, 2010) therefore organizations should care more in their performance.

Antony and Bhattacharyya (2010) examined the connection of the organizational excellence with the organizational performance in SMEs in India \& the results was, there is a possibility to be calculated by depending on the relationship among various for the organizational 
excellence indicators of performance. Furthermore, that relationship have been established \& tested according to the figures \& information received from 407 respondents in SMEs in India. The suggested \& proposed outcomes that organizational performance \& excellence come with measured by consolidating performance variables. Hence calculation of the organizational excellence can be through connection among performance variables.

Moreover, they found that organizational excellence helps managers to evaluate and differentiate organizations in better method that organizational performance.\& Therefore, the following hypothesis is proposed to be tested:

\section{H4: The organizational excellence moderates the relationship between TQM and organizational performance}

\subsection{Entrepreneurial orientation and Organizational Performance}

The historical definition was defined by the classic Joseph Schumpeter (1934) "The entrepreneurship is a deal we make related to a certain type of behaviour including initiative, organization and reorganization of socio-economic mechanisms and the acceptance or risks and failure". The activities of the Entrepreneurial have dramatically increased in such of the organizations as well as companies in the current period \& that increased also its successfully in the way to achieve an organizational performance \& constant competitive advantage (Covin\&Slevin, 1986; Wiklund\& Shepherd, 2003; Zahra, 1986).

There has been published bulk of research in the field of entrepreneurship and Entrepreneurial orientation (EO) concept. Although, entrepreneurial orientation (EO) has attracted interest of many writers, but the most majority of publications has come from USA authors and almost no empirical findings focus on Europe (Frank, Kessler, \& Fink, 2010). In addition, they argued that the works of Harms and Ehrmann (2003), Kreiser, Marino, and Weaver (2002a; 2002b; 2002c), Marino, Strandholm, Steensma, \& Weaver (2002), Wiklund (1998; 1999), Wiklund and Shepherd $(2003 ; 2005)$, and other some published doctoral thesis like Haid (2004) and Harms (2004), are exceptions, however most of them are not empirical studies.

Lumpkin and Dess (2001) studied the linking between two dimensions of EO and organization performance with investigating the moderating role of industry life cycle and environment using data collected from 124 executives from 94 organizations by survey instrument. Their finding suggested that the two dimensions, proactivesness and aggressiveness, have different effect on organizational performance. In other words, they found that proactiveness was positively related to performance but aggressiveness was poorly associated with performance. The following hypothesis is proposed to be examined:

H3: There is a significant relationship between EO and Organizational performance.

H3 a: There is a significant relationship between EO-Innovativeness and Organizational Performance.

H3 b: There is a significant relationship between EO-Proactiveness and Organizational Performance. 
H3 c: There is a significant relationship between EO-Risk-taking and Organizational Performance.

\section{Methodology}

The main purpose of this study is to examine the effect of variables of TQM, OE and EO on OP. To achieve that a quantitative methodology approach was employed. Questionnaire survey is considered as one of the important tools to gather the primary data from respondents (Kerlinger \& Lee, 2000). The data collected through cross-sectional research design which is suitable for this study to collect the data at the point of time. The survey questionnaires were distributed in March, 2015 and collected end of May, 2015 through hard copy and emails. The source of data was Al Ain Municipality in the UAE.

Because of the nature of this study's variables, various sections and departments of Al Ain Municipality have been selected to fill the questionnaire through Head of departments. Head of department are the middle managers as a link between managers and employees. They are aware more than others on how these practices and strategies how it can be implement it and working. Two hundred questionnaires have been distributed and one hundred thirty five were returned completely. Dimensions and measurements have been adopted and adapted from previous studies. TQM measurements have been adopted from: Brah, Wong, and Rao (2000), Anderson and Sohal (1999), Terziovski\& Samson (1999), and Rao (2000). Whereas measurements of organizational excellence have been adopted from Pinar and Girard (2000), and organizational performance from Kaplan and Norton $(1992 ; 2000)$. Structural Equation Modeling (SEM) is the technique that used to analyze the data and test the proposed hypothesis through Smart-PLS statistical software.

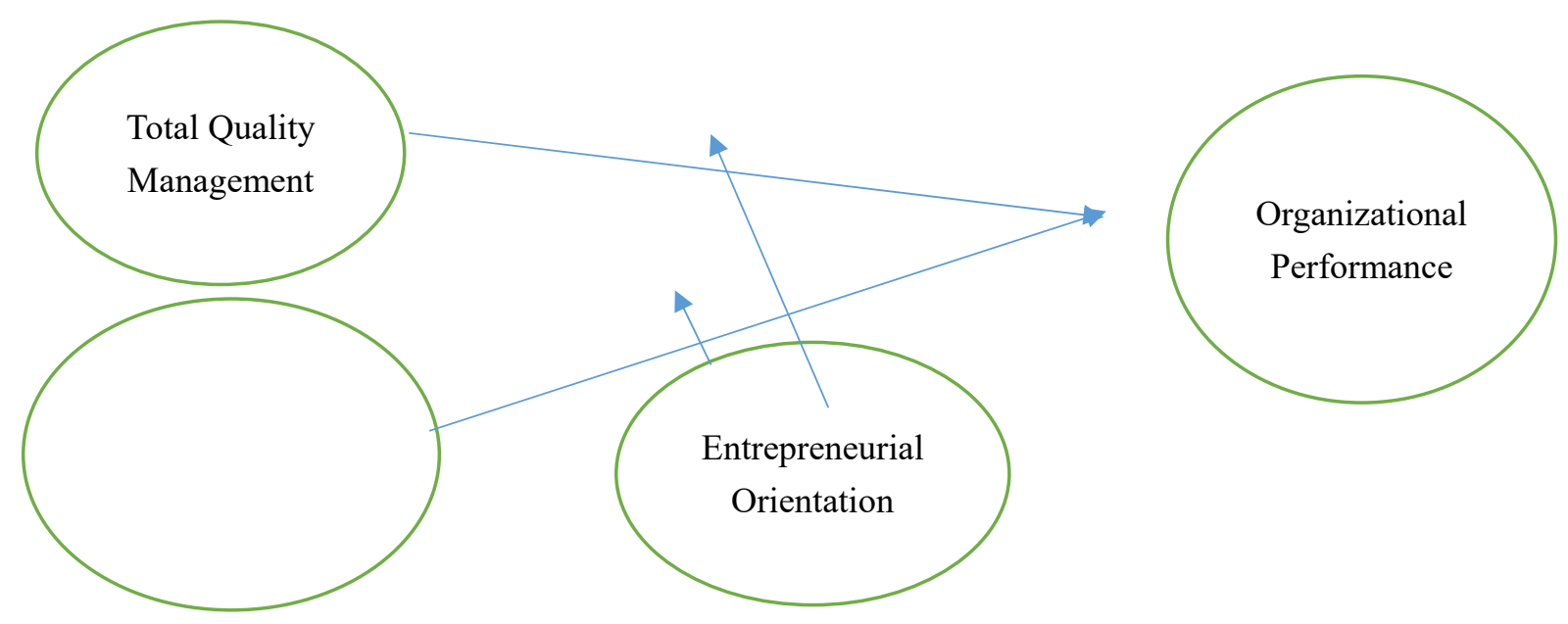

Figure 1. Theoretical Framework

\section{Statistical analysis and results}

Partial Least Square (PLS) is used to confirm the reliability and validity of the outer. As confirmed by various researchers, reliability and validity are the initial tests before doing the hypotheses testing. The model of this study contains the variables: TQM, organizational 
excellence, Entrepreneurial orientation and organizational performance. In order to examine the relationships between these variables, this study follows the two-step approach suggested by Chin (1998).In the literature of Structural Equation Modeling (SEM) the construct validity and reliability of the model should be approved before examining the hypothesized relationships.

\subsection{The Outer Model (Measurement)}

The following sections test the validity and reliability of the constructs before establishing the goodness of the measurement model. The construct validity and reliability was tested through the content validity, the discriminant validity, and the convergent validity as illustrated in the next sections.

\subsubsection{The Content Validity}

In multivariate analysis literature, the content validity of the construct compared with the other model's constructs. Therefore, Chin (1998) and Hair et al. (2010) suggested the using of factor loading to examine the content validity. To do that, the items will be deleted if are loaded high with other constructs than their respective ones. Table 1 and 2 showed that all the constructs are significantly loaded higher in their respective variables. Therefore, these results confirmed that the measurement model of this study has content validity.

\begin{tabular}{|c|c|c|c|c|c|c|c|c|c|c|c|c|c|c|}
\hline \multirow[t]{2}{*}{ Construct } & & B & CI & EOI & EOP & EOR & $\begin{array}{c}\text { CUSTOMER } \\
\text { FOCUS }\end{array}$ & INNOVATIONS & $\begin{array}{c}\text { PERSONNEL } \\
\text { COMMETMENT }\end{array}$ & IA & ML & OP & SD & SP \\
\hline & B1 & 0.879 & 0.813 & 0.655 & 0.576 & 0.665 & 0.604 & 0.666 & 0.657 & 0.735 & 0.743 & 0.546 & 0.671 & 0.732 \\
\hline \multirow[t]{3}{*}{ benchmark } & B2 & 0.891 & 0.681 & 0.556 & 0.531 & 0.580 & 0.502 & 0.584 & 0.541 & 0.631 & 0.605 & 0.440 & 0.608 & 0.588 \\
\hline & B3 & 0.898 & 0.741 & 0.624 & 0.573 & 0.615 & 0.532 & 0.622 & 0.610 & 0.661 & 0.643 & 0.526 & 0.700 & 0.596 \\
\hline & CI1 & 0.758 & 0.910 & 0.738 & 0.685 & 0.725 & 0.702 & 0.708 & 0.706 & 0.803 & 0.815 & 0.607 & 0.721 & 0.780 \\
\hline \multirow[t]{3}{*}{ continous improvement } & CI2 & 0.681 & 0.850 & 0.601 & 0.570 & 0.569 & 0.538 & 0.612 & 0.629 & 0.629 & 0.662 & 0.493 & 0.653 & 0.663 \\
\hline & CI3 & 0.800 & 0.902 & 0.696 & 0.602 & 0.692 & 0.628 & 0.700 & 0.713 & 0.772 & 0.787 & 0.590 & 0.705 & 0.748 \\
\hline & EOI1 & 0.649 & 0.703 & 0.918 & 0.810 & 0.793 & 0.611 & 0.702 & 0.682 & 0.650 & 0.658 & 0.535 & 0.646 & 0.642 \\
\hline \multirow[t]{2}{*}{ innovativness } & EOI2 & 0.642 & 0.731 & 0.933 & 0.808 & 0.832 & 0.608 & 0.689 & 0.673 & 0.675 & 0.685 & 0.541 & 0.615 & 0.700 \\
\hline & EOI3 & 0.625 & 0.692 & 0.921 & 0.800 & 0.792 & 0.572 & 0.668 & 0.662 & 0.635 & 0.648 & 0.534 & 0.640 & 0.656 \\
\hline \multirow{2}{*}{ proactivness } & EOP1 & 0.588 & 0.669 & 0.846 & 0.915 & 0.802 & 0.515 & 0.657 & 0.636 & 0.642 & 0.625 & 0.495 & 0.618 & 0.588 \\
\hline & EOP2 & 0.558 & 0.599 & 0.735 & 0.902 & 0.776 & 0.496 & 0.582 & 0.554 & 0.575 & 0.576 & 0.472 & 0.535 & 0.548 \\
\hline \multirow{3}{*}{ risk taking } & EOR1 & 0.594 & 0.684 & 0.795 & 0.820 & 0.891 & 0.543 & 0.614 & 0.602 & 0.589 & 0.633 & 0.532 & 0.541 & 0.587 \\
\hline & EOR2 & 0.581 & 0.629 & 0.772 & 0.710 & 0.869 & 0.499 & 0.586 & 0.586 & 0.627 & 0.614 & 0.450 & 0.545 & 0.552 \\
\hline & EOR3 & 0.673 & 0.663 & 0.732 & 0.758 & 0.878 & 0.484 & 0.596 & 0.591 & 0.590 & 0.613 & 0.519 & 0.617 & 0.523 \\
\hline \multirow{3}{*}{ customer fucus } & EXC1 & 0.495 & 0.584 & 0.563 & 0.487 & 0.485 & 0.902 & 0.599 & 0.619 & 0.573 & 0.644 & 0.578 & 0.567 & 0.673 \\
\hline & EXC2 & 0.540 & 0.616 & 0.587 & 0.503 & 0.538 & 0.930 & 0.651 & 0.633 & 0.610 & 0.703 & 0.618 & 0.584 & 0.680 \\
\hline & EXC3 & 0.597 & 0.663 & 0.562 & 0.486 & 0.510 & 0.822 & 0.709 & 0.750 & 0.635 & 0.690 & 0.612 & 0.680 & 0.657 \\
\hline \multirow{3}{*}{ innovations } & EXI1 & 0.654 & 0.721 & 0.670 & 0.622 & 0.624 & 0.700 & 0.923 & 0.789 & 0.692 & 0.732 & 0.588 & 0.651 & 0.685 \\
\hline & EXI2 & 0.640 & 0.701 & 0.709 & 0.652 & 0.643 & 0.671 & 0.926 & 0.728 & 0.675 & 0.716 & 0.601 & 0.649 & 0.686 \\
\hline & EXI3 & 0.675 & 0.705 & 0.700 & 0.638 & 0.639 & 0.703 & 0.949 & 0.814 & 0.682 & 0.747 & 0.592 & 0.690 & 0.716 \\
\hline \multirow{2}{*}{ personel commitment } & EXP1 & 0.629 & 0.705 & 0.654 & 0.615 & 0.599 & 0.705 & 0.767 & 0.899 & 0.665 & 0.720 & 0.623 & 0.717 & 0.684 \\
\hline & EXP2 & 0.655 & 0.744 & 0.699 & 0.642 & 0.644 & 0.706 & 0.801 & 0.917 & 0.687 & 0.725 & 0.585 & 0.690 & 0.727 \\
\hline
\end{tabular}




\begin{tabular}{|c|c|c|c|c|c|c|c|c|c|c|c|c|c|c|}
\hline \multirow[t]{2}{*}{ Construct } & & B & CI & EOI & EOP & EOR & $\begin{array}{c}\text { CUSTOMER } \\
\text { FOCUS }\end{array}$ & INNOVATIONS & $\begin{array}{c}\text { PERSONNEL } \\
\text { COMMETMENT }\end{array}$ & IA & ML & OP & SD & SP \\
\hline & EXP3 & 0.548 & 0.640 & 0.627 & 0.527 & 0.557 & 0.655 & 0.707 & 0.874 & 0.602 & 0.670 & 0.620 & 0.628 & 0.632 \\
\hline \multirow{5}{*}{ information \&anaylsis } & EXP4 & 0.594 & 0.655 & 0.612 & 0.552 & 0.605 & 0.636 & 0.696 & 0.878 & 0.630 & 0.672 & 0.550 & 0.599 & 0.636 \\
\hline & IA1 & 0.682 & 0.717 & 0.628 & 0.578 & 0.606 & 0.631 & 0.651 & 0.673 & 0.903 & 0.733 & 0.533 & 0.752 & 0.732 \\
\hline & IA2 & 0.687 & 0.749 & 0.653 & 0.631 & 0.632 & 0.634 & 0.672 & 0.667 & 0.920 & 0.750 & 0.547 & 0.734 & 0.777 \\
\hline & IA3 & 0.712 & 0.801 & 0.645 & 0.620 & 0.627 & 0.609 & 0.673 & 0.637 & 0.903 & 0.742 & 0.515 & 0.697 & 0.733 \\
\hline & ML1 & 0.672 & 0.778 & 0.669 & 0.625 & 0.659 & 0.692 & 0.724 & 0.699 & 0.713 & 0.925 & 0.631 & 0.683 & 0.762 \\
\hline \multirow{3}{*}{ leadership } & ML2 & 0.671 & 0.781 & 0.649 & 0.592 & 0.621 & 0.710 & 0.698 & 0.713 & 0.724 & 0.931 & 0.647 & 0.689 & 0.785 \\
\hline & ML3 & 0.693 & 0.748 & 0.657 & 0.606 & 0.645 & 0.703 & 0.724 & 0.693 & 0.784 & 0.895 & 0.572 & 0.668 & 0.782 \\
\hline & ML4 & 0.699 & 0.802 & 0.643 & 0.590 & 0.645 & 0.699 & 0.715 & 0.744 & 0.754 & 0.894 & 0.552 & 0.739 & 0.794 \\
\hline \multirow{4}{*}{ orgniztion performance } & OP1 & 0.470 & 0.541 & 0.511 & 0.463 & 0.473 & 0.637 & 0.579 & 0.582 & 0.531 & 0.628 & 0.849 & 0.535 & 0.561 \\
\hline & OP2 & 0.490 & 0.521 & 0.438 & 0.408 & 0.447 & 0.532 & 0.514 & 0.523 & 0.466 & 0.510 & 0.859 & 0.509 & 0.486 \\
\hline & OP3 & 0.449 & 0.511 & 0.495 & 0.424 & 0.470 & 0.608 & 0.525 & 0.531 & 0.489 & 0.542 & 0.841 & 0.487 & 0.533 \\
\hline & OP4 & 0.521 & 0.583 & 0.518 & 0.504 & 0.536 & 0.532 & 0.532 & 0.618 & 0.492 & 0.544 & 0.838 & 0.543 & 0.507 \\
\hline \multirow{2}{*}{ service desigh } & SD1 & 0.676 & 0.720 & 0.625 & 0.580 & 0.588 & 0.648 & 0.627 & 0.682 & 0.675 & 0.685 & 0.592 & 0.910 & 0.712 \\
\hline & SD2 & 0.681 & 0.706 & 0.626 & 0.581 & 0.589 & 0.617 & 0.671 & 0.668 & 0.784 & 0.706 & 0.528 & 0.915 & 0.701 \\
\hline \multirow{4}{*}{ strategic planing } & SP1 & 0.644 & 0.727 & 0.636 & 0.570 & 0.554 & 0.677 & 0.666 & 0.701 & 0.735 & 0.761 & 0.548 & 0.701 & 0.874 \\
\hline & SP2 & 0.656 & 0.754 & 0.629 & 0.515 & 0.546 & 0.677 & 0.673 & 0.700 & 0.721 & 0.768 & 0.529 & 0.711 & 0.895 \\
\hline & SP3 & 0.637 & 0.735 & 0.654 & 0.587 & 0.571 & 0.661 & 0.675 & 0.638 & 0.716 & 0.748 & 0.554 & 0.650 & 0.910 \\
\hline & SP4 & 0.643 & 0.728 & 0.653 & 0.563 & 0.579 & 0.692 & 0.649 & 0.646 & 0.764 & 0.781 & 0.573 & 0.701 & 0.891 \\
\hline
\end{tabular}

\section{The Convergent Validity}

The convergent validity is the degree of a group of items converges to measure a specific variable (Hair et al., 2010). In SEM literature, it can be confirmed by testing the composite reliability, the loading, and the average variance extracted (AVE). To consider the items are highly loaded and statistically significant, factor loading should at least 0.7 , AVE is at least 0.5 , and the composite reliability is at least 0.7 . Table 3 shows that all these criteria have been achieved and confirmed. Therefore, the results of the outer model (measurement model) have suitable convergent validity (Bagozzi \& Yi, 1988).

\begin{tabular}{cccccc}
\hline Construct & Items & Loadings & $\begin{array}{c}\text { Cronbach's } \\
\text { Alpha }\end{array}$ & CR $^{\mathbf{a}}$ & AVE $^{\mathbf{b}}$ \\
\hline \multirow{3}{*}{ benchmark } & B1 & $\mathbf{0 . 8 7 9}$ & & & \\
& $\mathbf{B 2}$ & $\mathbf{0 . 8 9 1}$ & 0.867923 & 0.9189 & 0.790668 \\
& $\mathbf{B 3}$ & $\mathbf{0 . 8 9 8}$ & & & \\
& $\mathbf{C l 1}$ & $\mathbf{0 . 9 1 0}$ & & & \\
continous improvement & $\mathbf{C l 2}$ & $\mathbf{0 . 8 5 0}$ & 0.865874 & 0.917923 & 0.788639 \\
& Cl3 & $\mathbf{0 . 9 0 2}$ & & & \\
& EOI1 & $\mathbf{0 . 9 1 8}$ & & & \\
innovativness & EOI2 & $\mathbf{0 . 9 3 3}$ & 0.914748 & 0.946233 & 0.854367 \\
& EOI3 & $\mathbf{0 . 9 2 1}$ & & &
\end{tabular}




\begin{tabular}{|c|c|c|c|c|c|}
\hline Construct & Items & Loadings & $\begin{array}{c}\text { Cronbach's } \\
\text { Alpha }\end{array}$ & $\mathbf{C R}^{\mathbf{a}}$ & $\mathbf{A V E}^{\mathbf{b}}$ \\
\hline \multirow{2}{*}{ proactivness } & EOP1 & 0.915 & \multirow{2}{*}{0.789038} & \multirow{2}{*}{0.904484} & \multirow{2}{*}{0.825632} \\
\hline & EOP2 & 0.902 & & & \\
\hline \multirow{3}{*}{ risk taking } & EOR1 & 0.891 & \multirow{3}{*}{0.853571} & \multirow{3}{*}{0.91106} & \multirow{3}{*}{0.773493} \\
\hline & EOR2 & 0.869 & & & \\
\hline & EOR3 & 0.878 & & & \\
\hline \multirow{3}{*}{ customer fucus } & EXC1 & 0.902 & \multirow{3}{*}{0.861092} & \multirow{3}{*}{0.915899} & \multirow{3}{*}{0.784475} \\
\hline & EXC2 & 0.930 & & & \\
\hline & EXC3 & 0.822 & & & \\
\hline \multirow{3}{*}{ innovations } & EXI1 & 0.923 & \multirow{3}{*}{0.925239} & \multirow{3}{*}{0.952558} & \multirow{3}{*}{0.870028} \\
\hline & EXI2 & 0.926 & & & \\
\hline & EXI3 & 0.949 & & & \\
\hline \multirow{4}{*}{ personel commitment } & EXP1 & 0.899 & \multirow{4}{*}{0.91443} & \multirow{4}{*}{0.939732} & \multirow{4}{*}{0.795904} \\
\hline & EXP2 & 0.917 & & & \\
\hline & EXP3 & 0.874 & & & \\
\hline & EXP4 & 0.878 & & & \\
\hline \multirow{3}{*}{ information \&anaylsis } & IA1 & 0.920 & \multirow{3}{*}{0.894632} & \multirow{3}{*}{0.934385} & \multirow{3}{*}{0.826001} \\
\hline & IA2 & 0.903 & & & \\
\hline & IA3 & 0.903 & & & \\
\hline \multirow{4}{*}{ leadership } & ML1 & 0.920 & \multirow{4}{*}{0.932007} & \multirow{4}{*}{0.951557} & \multirow{4}{*}{0.830865} \\
\hline & ML2 & 0.903 & & & \\
\hline & ML3 & 0.894 & & & \\
\hline & ML4 & 0.849 & & & \\
\hline \multirow{4}{*}{ orgniztion performance } & OP1 & 0.849 & \multirow{4}{*}{0.868882} & & \\
\hline & OP2 & 0.859 & & 0010411 & 0717575 \\
\hline & OP3 & 0.841 & & 0.510411 & בות \\
\hline & OP4 & 0.838 & & & \\
\hline $\mathrm{m}^{2}>$ & SD1 & 0.910 & 0700055 & o onerez & 0822655 \\
\hline serv1ce design & SD2 & 0.915 & 0.199050 & 0.908681 & 0.832055 \\
\hline & SP1 & 0.874 & & & \\
\hline & SP2 & 0.895 & 0014750 & & \\
\hline strateg1c planing & SP3 & 0.910 & $0.914 / 53$ & 0.93995 & 0.1965 \\
\hline & SP4 & 0.891 & & & \\
\hline
\end{tabular}

\section{The Discriminant Validity}

The literature of SEM defined the discriminant validity as the degree of items can distinguish a construct from other model's constructs. According to Compeau et al. (1999), items of each construct should have variances among them more than with other constructs in the model. Table 4 shows that the diagonal line of values that contain the square root of AVE and below it there are the correlations of the constructs. To examine the discriminant validity, the values of the diagonal line should be compared with other off diagonal ones. As we can see in the table, the values of the diagonal line are higher than others in their respective columns and 


\section{Macrothink}

Journal of Management Research

ISSN 1941-899X

2018, Vol. 10, No. 2

rows and therefore confirmed the discriminant validity of the model based on Fornell and Larcker's (1981) criterion.

\begin{tabular}{|c|c|c|c|c|c|c|c|c|c|c|c|c|c|}
\hline & B & CI & $\begin{array}{c}\text { CUSTOMER } \\
\text { FOCUS }\end{array}$ & EOI & EOP & EOR & IA & INNOVATIONS & ML & OP & $\begin{array}{c}\text { PERSONNEL } \\
\text { COMMETMENT }\end{array}$ & SD & $\mathbf{S P}$ \\
\hline B & 0.889 & & & & & & & & & & & & \\
\hline CI & 0.842 & 0.789 & & & & & & & & & & & \\
\hline $\begin{array}{c}\text { CUSTOMER } \\
\text { FOCUS }\end{array}$ & 0.617 & 0.705 & 0.784 & & & & & & & & & & \\
\hline EOI & 0.691 & 0.767 & 0.646 & 0.854 & & & & & & & & & \\
\hline EOP & 0.631 & 0.699 & 0.557 & 0.872 & 0.826 & & & & & & & & \\
\hline EOR & 0.700 & 0.749 & 0.579 & 0.872 & 0.868 & 0.773 & & & & & & & \\
\hline IA & 0.763 & 0.832 & 0.687 & 0.707 & 0.671 & 0.684 & 0.826 & & & & & & \\
\hline INNOVATIONS & 0.704 & 0.760 & 0.741 & 0.742 & 0.683 & 0.681 & 0.732 & 0.933 & & & & & \\
\hline ML & 0.750 & 0.853 & 0.769 & 0.718 & 0.662 & 0.705 & 0.816 & 0.785 & 0.912 & & & & \\
\hline OP & 0.570 & 0.637 & 0.683 & 0.581 & 0.532 & 0.570 & 0.585 & 0.636 & 0.659 & 0.847 & & & \\
\hline $\begin{array}{c}\text { PERSONNEL } \\
\text { COMMETMENT }\end{array}$ & 0.681 & 0.770 & 0.758 & 0.727 & 0.656 & 0.674 & 0.725 & 0.834 & 0.782 & 0.667 & 0.892 & & \\
\hline SD & 0.744 & 0.781 & 0.693 & 0.685 & 0.636 & 0.645 & 0.800 & 0.712 & 0.762 & 0.613 & 0.739 & 0.912 & \\
\hline SP & 0.723 & 0.825 & 0.759 & 0.720 & 0.626 & 0.630 & 0.823 & 0.746 & 0.857 & 0.618 & 0.752 & 0.774 & 0.892 \\
\hline
\end{tabular}

The Inner Model (Structural Model), and Hypotheses Testing

\section{Testing the Direct Hypotheses}

After testing the validity and reliability of the construct, the next step is to examine in the inner model through hypotheses testing by running Algorithm and Bootstrapping in PLS. Figure 2 and Table 5 illustrated the results.

The Results of the Inner Structural Model

\begin{tabular}{ccccccc}
\hline \multirow{2}{*}{ Hypothesis } & Hypothesis & $\begin{array}{c}\text { Path } \\
\text { Coefficient }\end{array}$ & $\begin{array}{c}\text { Standard } \\
\text { Error }\end{array}$ & $\begin{array}{c}\text { T } \\
\text { Value }\end{array}$ & $\begin{array}{c}\text { P } \\
\text { Value }\end{array}$ & Decision \\
\hline H1 & TQM $>$ OP & 0.217 & 0.105 & 2.065 & 0.020 & Supported \\
H2 & OE $>$ OP & 0.526 & 0.105 & 5.000 & 0.000 & Supported \\
\hline
\end{tabular}

$*: \mathrm{p}>0.05 ; * *: \mathrm{p}>0.01 ; * * *: \mathrm{p}>0.01$

Figure 2 and Table 5 show that all the two hypotheses have positive and significant results at the 0.001 level of significance $(\beta=0.130, \mathrm{t}=2.065, \mathrm{p}<0.001), \quad(\beta=0.526, \mathrm{t}=5.000$, $\mathrm{p}<0.001)$ Respectively. Accordingly, these outcome supported the hypotheses of the study H1, $\mathrm{H} 2$

\section{Predictive Relevance of the Model}


R-square, cross-validated redundancy and cross-validated communality were employed to test the predictive power of the model. According to Cohen (1988), values of R-square are substantial with 0.26 , moderate with 0.13 , and weak with 0.02 . All values in the table of $\mathrm{R}$-square are considered substantial. Cross-validated redundancy and cross-validated communality are the medium to assess the model's quality. To extract them, blindfolding procedure in PLS was employed. Their values should be more than zero to say that the model has predictive quality (Fornell \& Cha, 1994). Table 7 shows values more than zero and therefore confirmed that the model has prediction quality.

Predictive Quality Indicators of the Model

\begin{tabular}{lcccc}
\hline Variable & Variable & R & & \\
Type & Cross-Validated & Cross-Validated \\
square & Communiality & Redundancy \\
Organizational Performance (OP) & Endogenous & 0.5 & 0.718 & 0.373 \\
\hline
\end{tabular}

\section{Goodness of Fit (GOF) of the Model}

According to Wetzels et al. (2009), GoF can be confirmed based on the criteria: (small $=0.1$, medium $=0.25$, large $=0.36$ ). Table 8 below shows that the GoF value was 0.613 which considered large value.

\begin{tabular}{lccc}
\hline Construct & R Square & Average Variance Extracted & Goodness of Fit \\
\hline Organizational Performance & 0.524 & 0.718 & 0.613 \\
\hline
\end{tabular}

\section{Discussion and Conclusion}

This purpose of the study to examine the effect of TQM, organizational excellence, Entrepreneurial orientation on organizational performance. Due to the inconsistency in the literature of the effect TQM, organizational excellence and Entrepreneurial orientation on organizational performance. One moderator variables have been proposed as mechanisms to explain this relationship in different context. These variables are organizational excellence. As expected from the nature and the integration between variables, all hypotheses have been confirmed. In addition, in consistent with other previous studies, all variables has been found to have a positive and significant effect on organizational performance $(\beta=0.130, t=2.065$, $\mathrm{p}<0.001),(\beta=0.526, \mathrm{t}=5.000, \mathrm{p}<0.001)$.

In line with other previous studies, TQM was found to have a positive and significant effect at 0.001 level of significance $(\beta=0.130, \mathrm{t}=2.065, \mathrm{p}<0.001)$, (Chong \& Rundun, 2004; Hassan $\&$ Kerr, 2003). This study has many theoretical contributions. Besides examining the positive effect among variables due to the inconclusiveness finding in the previous literature. In addition, this study fills the gap in the literature by examining the moderating effect of 
Entrepreneurial orientation on the relationship between TQM and organizational excellence on organizational performance. The results of this study will urge other researchers to investigate and examine other factors that may play some roles in these relationships. The framework of this study is a unique framework which suggested new relationships which never studied before. In practice, the findings of this study have different practical implications. This study clears the way to managers and decision makers to involve TQM and excellence in their organizations.

There are some limitations of this study. Similar to other previous research surveys, the data collected through self-reported which considered one of common method bias (Thornton, 2006).

Cross-sectional as the research design of this study was used which considered another limitation. The biasness may also generate from the self-reported answers where the respondents translate their perceptions through the questionnaire. Therefore, future researches should include the mixed method design. In addition, longitudinal researches should be considered to test the effects of TQM, organizational Excellence and Entrepreneurial orientation on organizational performance in different point of times.

\section{References}

Ahire, S. L., Landeros, R., \&Golhar, D. Y. (1995). Total quality management: A literature review and an agenda for future research. Production and Operation Management, 4(3), 227-306. https://doi.org/10.1111/j.1937-5956.1995.tb00057.x

Anderson, M., \& Sohal, A. S. (1999). A study of the relationship between quality management practices and performance in small businesses. International Journal of Quality \& Reliability Management, 16(9), 859-877. https://doi.org/10.1108/02656719910289168

Antony, J. P, \& Bhattacharyya, S.(2010). Measuring organizational performance and organizational excellence of SMEs - Part 2: an empirical study on SMEs in India. Measuring Business Excellence, 14(3), 42-52. https://doi.org/10.1108/13683041011074209

Bagozzi, R. \& Yi, Y. (1988). On the evaluation of structural equation models. Journal of the Academy of Marketing Science, 16(1), 74-94. https://doi.org/10.1007/BF02723327

Brah, S. a., Wong, J. L., \& Rao, B. M. (2000). TQM and business performance in the service sector: a Singapore study. International Journal of Operations \& Production Management, 20(11), 1293-1312. https://doi.org/10.1108/01443570010348262

Brah, S. a., Wong, J. L., \& Rao, B. M. (2000). TQM and business performance in the service sector: a Singapore study. International Journal of Operations \& Production Management, 20(11), 1293-1312. https://doi.org/10.1108/01443570010348262

Chong, V. K., \&Rundus, M. J. (2004). Total quality management, market competition and organizational performance. The British Accounting Review, 36(2), 155-172. https://doi.org/10.1016/j.bar.2003.10.006

Compeau, D., Higgins, C.A., \& Huff, S. (1999). Social Cognitive Theory and individual 
Reactions to Computing Technology - A Longitudinal-Study. MIS quarterly, 23(2), 145-158. 376. https://doi.org/10.2307/249749

Covin, J. G., \& Slevin, D. P. (Eds.). (1986). The Development and Testing of an organizational level Entrepreneurship Scale. Wellesley, MA: Babson College.

Fornell, C., \& Larcker, D. F. (1981). Evaluating structural equation models with unobservable variables and measurement error. Journal of Marketing Research, 18(1), 39-50. https://doi.org/10.2307/3151312

Fornell, C., \& Cha, J. (1994). Partial least squares. Advanced methods of marketing research, 407, 52-78.

Frank, H., Kessler, A., \& Fink, M. (2010). Entrepreneurial Orientation and Business Performance - A Replication Study. Schmalenbach Business Review, 62, 175-198. https://doi.org/10.1007/BF03396804

Haid, D. (2004). Corporate

EntrepreneurshipimstrategischenManagement.AnsatzzurImplementierung des Unternehmertumsim Unternehmen, Wiesbaden: DeutscherUniversitätsverlag.

Hair, J. F., Anderson, R. E., Tatham, R. L., \& Black, W. C. (2010). Multivariate Data Analysis. Seventh Edition. Prentice Hall. New Jesey. 396

Harms, R., \& Ehrmann T. (2003). The Performance Implications of Entrepreneurial Management: Linking Stevenson's and Miller's Conceptualization to Growth, Paper presented at the Babson Kauffman Research Conference on Entrepreneurship, MA: Babson College.

Harms, R. (2004). Entrepreneurship in Wachstumsunternehmen, Wiesbaden: Deutscher Universitätsverlag. https://doi.org/10.1007/978-3-322-81802-7

Hassan, M., \& Kerr, R. M. (2003). The relationship between total quality management practices and organizational performance in service organizations. The TQMMagazine, 15(4), 286-291. https://doi.org/10.1108/09544780310486191

Kanji, G. (2002). Measuring Business Excellence. London: Routledge.

Kaplan, R. S., \& Norton, D. P. (2000). Having trouble with your strategy? Then map it. Harvard Business Review, 78(5), 167-176.

Kaplan, R.S., \& Norton, D.P. (1992). The balanced scorecard \pm measures that drive Performance. Harvard Business Review, January-February, 70-79.

Karuppusami, G., \& Gandhinathan, R. (2006). Pareto analysis of critical success factors of total quality management. A literature review and analysis. The TQM Magazine, 18(4), 372-85. https://doi.org/10.1108/09544780610671048

Kerlinger, F. N., \& Lee, H. B. (2000). Foundations of behavioral research. 4th ed. Harcourt College Publishers: Orlando, US.

Kreiser, P. M., Marino, L. D., \& Weaver, K. M. (2002a). Reassessing the Environment-EO 
Link: The Impact of Environmental Hostility on the Dimensions of Entrepreneurial Orientation. Academy of Management Proceedings, G1-G6.

Kreiser, P. M., Marino, L. D., \& Weaver, K. M. (2002a). Reassessing the Environment-EO Link: The Impact of Environmental Hostility on the Dimensions of Entrepreneurial Orientation, Academy of Management

Lumpkin, G. T., \& Dess, G. G. (2001). Linking two dimensions of entrepreneurial orientation to firm performance: the moderating role of environment and industry life cycle. Journal of Business Venturing, 16, 429-451. https://doi.org/10.1016/S0883-9026(00)00048-3

Mcadam, R. (2000). Perspectives Three leafed clover ?: TQM , organisational excellence and business improvement empowerment concepts; improvements in productivity. The TQM Magazine, 12(5), 314-320 https://doi.org/10.1108/09544780010341897

Oakland Consultation (2005). Leadership and policy deploymeny-the backbone of TQM, John Oaklan Paper for TQM \&Busi

Peters, T., \& Waterman, R. (1982). In Search of Excellence: Lessons from America's Best-Run Companies. New York: Harper \& Row.

Pinar, M., \& Girard, T. (2008). Investigating the Impact of Organizational Excellence and Leadership on Business Performance: An Exploratory Study of Turkish Firms. SAM Advanced Management Journal, 73(1), 29-45.

Samson, D., \& Terziovski, M. (1999). The relationship between total quality management practices and operational performance. Journal of Operations Management, 17(4), 393-409. https://doi.org/10.1016/S0272-6963(98)00046-1

Schumpeter, J. (1934). The Theory of Economic Development, Cambridge, MA: Harvard University Press.

Sila, I. (2007). Examining the effects of contextual factors on TQM and performance through the lens of organizational theories: An empirical study. Journal of Operations Management, 25, 83-109. 445. https://doi.org/10.1016/j.jom.2006.02.003

Wetzels, M., Odekerken-Schroder, G., \& Van Oppen, C. (2009). Using PLS path modeling for assessing hierarchical construct models: Guidelines and empirical illustration. Mis Quarterly, 33(1), 177. https://doi.org/10.2307/20650284

Wiklund, J. (1999). The sustainability of entrepreneurial orientation (EO)-performance relationship. Entrepreneurship Theory and Practice, 24(1), 37-48. https://doi.org/10.1177/104225879902400103

Wiklund, J., \& Shepherd, D. (2003). Knowledge-based resources, entrepreneurial orientation, and the performance of small and medium-sized businesses. Strategic Management Journal, 24(13), 1307-1314. https://doi.org/10.1002/smj.360

Wiklund, J., \& Shepherd, D. (2003). Knowledge-based resources, entrepreneurial orientation, and the performance of small and medium-sized businesses. Strategic Management Journal, 
24(13), 1307-1314. https://doi.org/10.1002/smj.360

Wiklund, J., \& Shepherd, D. (2003). Knowledge-based resources, entrepreneurial orientation, and the performance of small and medium-sized businesses. Strategic Management Journal, 24(13), 1307-1314. https://doi.org/10.1002/smj.360

Wiklund, J., \& Shepherd, D. (2005). Entrepreneurial orientation and small business performance: a configurational approach. Journal of Business Venturing, 20(1), 71-91. https://doi.org/10.1016/j.jbusvent.2004.01.001

Zahra, S.A. (1986). A Canonical Analysis of Corporate Entrepreneurship Antecedents and Impact on Performance. Proceedings of the National Academy of Management, 46, 71-5. https://doi.org/10.5465/AMBPP.1986.4978718 